YEARBOOK of ANTITRUST and REGULATORY STUDIES www.yars.wz.uw.edu.pl
Peer-reviewed scientific periodical, focusing on legal and economic issues of antitrust and regulation. Creative Commons Attribution-No Derivative Works 3.0 Poland License.

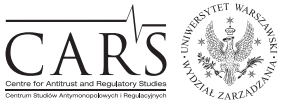

Centre for Antitrust and Regulatory Studies, University of Warsaw, Faculty of Management www.cars.wZ.uw.edu.pl

\title{
Gas Insulated Switchgear Cartel in the Slovak Republic
}

\author{
by
}

\section{Silvia Sramelova*}

\section{CONTENTS $^{* *}$}
I. Introduction
II. Parental liability
III. Parallel competences - the European Commission and the AMO
IV. Reformatio in peius
V. Conclusions

Key words: cartel; parallel competences; parental liability; reformatio in peius; Slovak competition authority.

JEL: K21

\section{Introduction}

The case of the Gas insulated switchgear (hereafter, GIS) cartel is well known to competition experts all over Europe. The cartel lasted for more than twenty years and affected competition on relevant markets in several countries. Following leniency applications submitted by one of its participants, the case was brought before several competition authorities in the European Union, including the European Commission and the Antimonopoly Office of the Slovak Republic (hereafter, AMO).

* Lawyer, the Antimonopoly Office of the Slovak Republic, Legal and International Relations Division; silvia.sramelova@antimon.gov.sk.

** Article received: 26 April 2016; accepted: 15 May 2016. 
In 2009, the AMO took a cartel decision covering the biggest producers of GIS, including several Japanese and European undertakings ${ }^{1}$. According to the decision, 20 GIS producers infringed the Slovak Act on the Protection of Competition ${ }^{2}$. The cartel consisted of various forms of infringements such as: price fixing, stabilization of market shares on the basis of pre-agreed quotas, bid rigging etc. Japanese and European companies participated in cartel activities on a worldwide level. On the basis of the cartel agreements, Japanese and European GIS producers agreed that Japanese companies will not enter the European market and vice versa. Moreover, European GIS producers concluded anti-competitive agreements with each other, which were applied directly in Europe, including Slovakia. The AMO identified several public tenders in the Slovak Republic directly affected by this cartel. The $\mathrm{AMO}^{3}$ imposed a fine totaling 8628390 EUR.

The AMO initiated the proceedings on the basis of a leniency application submitted by the members of the economic group $\mathrm{ABB}^{4}$. The leniency applicant provided the AMO with all relevant documents and information necessary to prove the infringement.

From the Slovak perspective, the case was interesting for several reasons.

1) It was the first case where the AMO referred to the principles of the parental liability concept according the case law of the European Commission and the jurisprudence of the Court of Justice of the European Union (hereafter, CJEU).

2) The case was dealt with in parallel by various competition authorities within the European Union - a fact that brought up ne bis in idem issues and questions concerning the application of Regulation 1/2003. This lead to a preliminary proceeding before the CJEU.

3 ) In this case, the Council of the AMO (the $2^{\text {nd }}$ instance body within the structure of the AMO) increased the fine imposed within the $1^{\text {st }}$ instance proceedings. Thus, the AMO responded to objections about the breach of the reformatio in peius principle. The issue was finally resolved by the Slovak Constitutional Court.

${ }^{1}$ Decisions No 2007/KH/1/1/109 of 28 December 2007 and 2009/KH/R/2/035 of 14 August 2009. The AMO decides on cases on the basis of a two instance system. The executive department of the AMO decides on the case in the $1^{\text {st }}$ instance. This decision may then be reviewed by the Council of the AMO. After the $2^{\text {nd }}$ instance decision is taken, the case may be brought before the court. The text below uses the term 'the decision' in this context. The distinction is made only where it is necessary.

2 Act No 136/2001 Coll. On Protection of Competition

3 The text below uses the term 'AMO' to refer both to the Council of the AMO and the $1^{\text {st }}$ instance body. The distinction is made only where it is necessary.

${ }^{4}$ ABB Management Services Ltd, ABB Switzerland Ltd, ABB Ltd. 
The case was reviewed by Slovak courts in separate judicial proceedings (i.e. separate proceedings on the basis of separate actions submitted before the courts). Whereas the Regional Court in Bratislava annulled the decision of the AMO, the Supreme Court amended these judgments and dismissed the actions ${ }^{5}$.

\section{Parental liability}

According to the evidence submitted by the leniency applicant, the members of the cartel ${ }^{6}$ belonged to several economic entities. The evidence indicated that within their economic groups, both parents and their subsidiaries participated in the cartel. Moreover, during the course of the cartel, some of its members ceased to exist, or transferred their economic activities to other companies.

The Slovak Act on the Protection of Competition does not explicitly foresee the application of the parental liability concept. The decisions of the AMO are always addressed to persons with legal standing. The Act on the Protection of Competition does not contain any specific legal provisions on the liability of an 'economic entity', nor provisions concerning several and joint liability for fines. Nevertheless, 'economic reality' makes it impossible for the AMO to see legal persons completely separately from the economic group to which they belong?

The GIS cartel was the first case for the AMO to explicitly refer to the parental liability concept as it is applied in the European Union (in particular to the $100 \%$ presumption), even though Article 101 TFEU was not applied in this case but rather, only its Slovak equivalent.

5 Though the case was reviewed in separate judicial proceedings, the conclusions/ findings in of the courts were similar. The text below refers to a specific judgement only where it is necessary.

Some of the proceedings are still open before the Supreme Court. However, most of the proceedings have already been closed (7Sžhpu1/2013, 8Sžhpu/4/2013, 3Sžhpu/1/2013, 8Sžhpu 1,2,3/2013, 2Sžhpu/1/2013, 5 Sžhpu/1/2014. On 28 April 2016, the Supreme Court delivered the judgement as regards the complainant Siemens Aktiongesellschaft Österreich (5 Sžhpu/1/2014). In this case, the Supreme Court annulled the decision of the AMO to the extent related to the complainant. The decision of the AMO was annulled mostly for the 'insufficient reasoning of the imposed fine'.

6 I.e. legal persons.

7 This could be seen e.g. in the Decree of the Antimonopoly Office of the Slovak Republic of 19 June 2014 172/2014 Coll. laying down details of leniency programme, according to which a leniency application may not be submitted by more than one undertaking at the same time, unless they belong to the same economic group. 
It is clear from the text of the decision that the AMO (taking into account the differences between the Slovak legal system and that of the EU) endeavored to find evidence of each parent company's and its subsidiary's direct participation in the infringement. However, the AMO was unable to identify the exact form of each company's participation in the cartel - the evidence submitted by the leniency applicant mostly showed the participation in the cartel of economic entities as such (rather than specifically the participation of individual members of such economic entities).

The AMO stressed in its decision that imposing a fine only upon a parent company, despite the fact that both parent and its subsidiaries infringed competition rules, could make the fine not proportionate to the profit gained by the infringement. Thus, the sanction would not have a sufficient deterrent effect. The AMO underlined the importance of imposing a fine that is proportionate to the strength and importance of the economic entity at stake.

The Slovak Act on the Protection of Competition does not permit the imposition of a single fine for which both the parent and its subsidiary would be liable. Fines must be therefore calculated separately for each legally entity.

In the calculation of the final amount of the fine ${ }^{8}$, the AMO took into account the fact that participants are part of the same economic entity. Similarly to the decision of the European Commission, for the purpose of the calculation of fines, the AMO first divided the participants according to their relation to the economic entities, and then took into account the economic strength of each economic entity.

The Regional Court in Bratislava agreed with the AMO, in so far as the AMO decided that an infringement of the Act on the Protection of Competition took place and that the infringement affected the territory of the Slovak Republic. The Court also agreed that the economic entities identified in the decision infringed competition rules.

However, according to the Regional Court in Bratislava, the AMO failed to clarify to what an extent each of the cartel members (i.e. each legal person) contributed to the functioning of the cartel. The Court stressed the principle of 'individual and personal liability' for the infringement. It thus came to the conclusion that it is necessary to take into account the role of each cartel member in the infringement. Not doing so would result in a situation where those that participate in a cartel as part of a larger economic group would be in a worse position than those who partake on their own. According to

8 The AMO did not use its Guidelines on the procedure for setting the fines in cases of abuse of dominant position and agreements restricting competition from 2008 (since the Guidelines entered into force after the adoption of the $1^{\text {st }}$ instance decision) http://www. antimon.gov.sk/data/files/16_metodicky-pokyn_pokuty.pdf 
the Regional Court in Bratislava, it is necessary to prevent an undesirable accumulation of fines.

By contrast, the Slovak Supreme Court came to the conclusion that the AMO had sufficiently identified the role of each cartel participants in its infringement decision and had given sufficient reasons for the fine which it had imposed. However, the Supreme Court did not explicitly refer to the parental liability concept, nor clarified the possibility of applying this concept in Slovak competition proceedings.

\section{Parallel competences - the European Commission and the AMO}

Since the case was brought before several competition authorities across the European Union, the AMO had to deal with the interpretation of the provisions of Regulation $1 / 2003^{9}$ on the division of competences between the European Commission and National Competition Authorities (hereafter, NCAs).

The AMO issued its own decision after the adoption of the decision by the European Commission. The latter set the date of the cessation of the cartel to 11 May 2004 (11 days after the accession of the Slovak Republic to the EU). Unlike the Commission, the AMO set the date of the cessation of the cartel to 30 April 2004 - a decision reasoned by doubts about the competences of the AMO to assess the infringement after this date (this question was ultimately left open in the decision $)^{10}$.

Importantly, according to the AMO, the decision of the European Commission did not cover the territory of the Slovak Republic.

The applicants primarily argued that the proceedings brought at the national level infringed the ne bis in idem principle, prohibiting the undesirable accumulation of penalties. According to their claim, the AMO had determined the duration of the cartel in an erroneous manner, since it had set the cessation of the cartel to a date prior to the accession of the Slovak Republic to the European Union. According to those applicants, it follows from Article 11(6) of Regulation $1 / 2003^{11}$ that the AMO did not have the power to start proceedings

9 Council Regulation (EC) No. 1/2003 of 16 December 2002 on the implementation of the rules on competition laid down in Articles 81 and 82 of the Treaty (OJ 2003 L 1/1), hereafter, Regulation 1/2003.

10 See para. 135 of the $2^{\text {nd }}$ instance decision of the AMO

11 ' 6 . The initiation by the Commission of proceedings for the adoption of a decision under Chapter III shall relieve the competition authorities of the Member States of their competence to apply Articles 81 and 82 of the Treaty. If a competition authority of a Member State is already acting on a case, the Commission shall only initiate proceedings after consulting with that national competition authority'. 
at the national level since the European Commission had already initiated proceedings at the EU level in the same case.

Incidentally, the same cartel had at that time already become the subject of an investigation by the NCA of the Czech Republic (the Office for the Protection of Competition) and so the problem of parallel competences arose first in the Czech proceedings. The reviewing court, the Regional Court in Brno, used the preliminary ruling procedure to ask the CJEU to provide guidance on the question of parallel competences of NCAs to assess a case already investigated by the Commission. ${ }^{12}$ In view of these developments, Slovak courts suspended their proceedings awaiting the ruling of the CJEU.

The CJEU stressed in its judgment ${ }^{13}$ that the provisions of Article 81 EC (now 101 TFEU) and Article 3(1) of Regulation 1/2003 are applicable to the possible anti-competitive effects of the cartel at issue in the main proceedings on the Czech territory only in so far as it is necessary to impose penalties for those effects inasmuch as they were produced during the period which began on 1 May 2004.

The court further added that applicants in the main proceedings do not advocate the application of a more lenient penalty for the period before 1 May 2004, but are in reality seeking to obtain a situation in which the Czech NCA takes no final decision as regards the effects of the cartel in question on the Czech territory. Those companies want the principle of the retroactive application of the more lenient penalty to be ultimately interpreted as meaning that the NCA does not have the power to penalize that cartel for the period before 1 May 2004, and that the anti-competitive effects produced by the latter during that period are considered as covered by the decision of the European Commission.

The CJEU came to the conclusion that the decision of the Commission does not cover any anti-competitive effects of the cartel in the territory of the Czech Republic in the period prior to 1 May 2004. According to the Court, the ne bis in idem principle does not preclude penalties which the NCA of the Member State concerned imposes on cartel participants on account of the anti-competitive effects to which the cartel gave rise in the territory of that Member State before its EU accession, where the fines imposed on the same cartel members by a Commission decision (taken before the decision of that NCA was adopted) were not designed to penalize the said effects.

Slovak courts took into account the abovementioned conclusions and referred to the judgment of the CJEU. Thus they did not provide a further analysis in this respect.

12 The Slovak government submitted its observations to the CJEU in the proceedings as well.

13 C-17/10 Toshiba Corporation v. the Office on Protection of Competition (Czech Republic), ECLI: EU: C:2012:72. 


\section{Reformatio in peius}

Reformatio in peius is a common legal principle applied in criminal law in the Slovak Republic. The principle stems from the Roman law rule: 'Reformatio in peius iudici appellato non licet' which essentially means that nobody should be placed in a worse position as a result of filing an appeal. The principle is a key part of the right of defence and works as a guarantee that everybody could use his/her right of defence without concern that his/her position will worsen as a result (Ivor, 2010, p. 704-705) ${ }^{14}$.

The application of this principle is part of a long-lasting discussion on the application of criminal law principles to administrative offences ${ }^{15}$.

Neither the Administrative Procedural Code ${ }^{16}$, nor the Act on the Protection of Competition, have specific provisions on 'reformatio in peius' in administrative (or competition) proceedings.

The AMO is a body that both investigates and decides on a competition law infringement. As mentioned, the AMO decides in two instances. The $2^{\text {nd }}$ instance body (the Council of the AMO) decides on the basis of an appeal. However, once the $1^{\text {st }}$ instance decision is appealed, the Council of the AMO does not limit its review to the grounds of the appeal only but actually reviews the decision as a whole. After the procedure, the undertaking can bring the case before the court. The court reviews the legality of the decision of the AMO within the terms of the claim.

14 This principle is applied in criminal proceedings in an appeal procedure, together with the principle beneficium cohaesionis (according to this principle, the decision appealed by one of the accused could be changed in favour of the others even though they did not submit the appeal). The reformatio in peius principle is applied in the $2^{\text {nd }}$ instance proceedings as well as in the subsequent $1^{\text {st }}$ instance proceedings if the $1^{\text {st }}$ instance decision is annulled).

15 Competition law infringements belong to the group of the so called 'other administrative offences'. These include offences committed by natural and legal persons in various branches of the law such as: offences in the area of environmental law, offences in construction law, etc. Unlike minor offences, 'other administrative offences' are regulated by a number of different laws. When it comes to substantive legal rules, they lack lex generalis. Both the substantive aspects of 'other administrative offences' and their procedural particularities are regulated by lex specialis. As regards procedural issues, the function of lex generalis is fulfilled by the Administrative Procedural Code. Albeit the Administrative Procedural Code regulates the procedural aspect of the assessment of 'other administrative offences', it does not cover general questions such as: the basic principles for the imposition of fines, the application of exculpatory circumstances, etc. This altum silentium may be replaced by the application of analogy with a branch of law that possess the relevant legal rules e.g. by the application of criminal law principles. Analogy with criminal law is however quite disputable. See also (Sramelova and Blazo, 2015).

16 The Administrative Procedural Code no 71/1967 Coll. 
By contrast, in criminal proceedings, the crime is investigated by the police. The court decides both on the crime and on the punishment. The judgment can be appealed by either the state attorney or the by the accused. The reformatio in peius principle is applied only if the judgment is appealed by the accused.

In the case at hand, the Council of the AMO decided to increase the fine imposed in the $1^{\text {st }}$ instance with respect to one of the cartel members, SIEMENS AG. The Council of the AMO believed that it was necessary to take into account the special role which SIEMENS AG had played in the cartel - according to evidence, SIEMENS AG acted as the coordinator of the cartel and significantly facilitated its functioning. This has lead the Council of the AMO to decide to increase the fine originally imposed on SIEMENS AG in the $1^{\text {st }}$ instance decision by an additional $40 \%$.

While reviewing the case, the Regional Court ${ }^{17}$ referred to the European Convention on Human Rights and fundamental freedoms (hereafter, ECHR). In its view, forasmuch as the court reviews the decision where the fine was imposed, it is necessary to apply Article 6 ECHR. The Regional Court referred also to the Council of Europe's Recommendation No (91) 1 of the Committee of Ministers to Member States on Administrative sanctions (hereafter, Recommendation) ${ }^{18}$. The Recommendation lays down the basic principles which should be followed in administrative procedures - most of them derive from criminal proceedings.

The Regional Court stressed that it was necessary to apply criminal law principles to the proceedings at hand. Hence, it was necessary to go with the more favorable treatment when it comes to the accused company.

By contrast, the Supreme Court ${ }^{19}$ did not share the view of the Regional Court with regard to the application of the reformatio in peius principle. In its judgment, the Supreme Court provided a detailed analysis of its own jurisprudence as well as that of the judicature of the Czech Republic, the ECtHR and of the CJEU.

First, the Supreme Court dealt with the application of criminal law principles to administrative proceedings. In its previous rulings, the Slovak Supreme Court stated that administrative sanctions must be subject to the same regime as those imposed in criminal proceedings ${ }^{20}$. In this judgement,

17 Judgement of the Regional Court in Bratislava of 28 May 2013 in case 3S228/2009.

18 Recommendation was adopted on administrative sanctions on 13 February 1991 by the Committee of Ministers to Member States.

19 Judgement of the Supreme Court of the Slovak Republic of 9 June 2015 3Sžhpu1/2003.

20 E.g. Judgement of the Supreme Court of 24 November 2011 in case no 8 Sž 18/2011, 8 Sž 22/2011, 8 Sž 23/2011 a 8 Sž 24/2011 of 24 November 2011. 
the Supreme Court referred to the Engel criteria ${ }^{21}$, which must be analysed to uncover whether the sanctions are of a criminal nature. It further referred to the jurisprudence of the ECtHR according to which the ECHR makes a distinction between 'hard core criminal law' and 'other offences' (including competition law infringements), where 'criminal' guarantees will not necessarily apply with their full stringency 22 .

In the case at hand, the Supreme Court said that the substantive part of criminal law guarantees applies also to administrative proceedings, where administrative sanctions are imposed. However, the Supreme Court also stressed that it is not possible to conclude from the Recommendation that all rights immanent to criminal law procedures are applicable to administrative proceedings as well.

The Supreme Court emphasized the particularities of administrative proceedings in comparison to criminal procedures, especially the right of the administrative body to review the $1^{\text {st }}$ instance decision as a whole, and the obligation of the $2^{\text {nd }}$ instance administrative body to annul or amend every decision which is in breach of the law. Moreover, it pointed out that in a criminal procedure, the public interest is represented by the state attorney, which could acquire the imposition of stricter punishment following his/her own appeal.

The Supreme Court referred also to the rulings of the Constitutional Court of the Czech Republic, which had concluded that it is not possible to derive from the Constitution that the principle is applied also in the area of administrative sanctions. It also pointed towards the judgments of the CJEU ${ }^{23}$ where the latter increased the fines imposed by the European Commission.

The Supreme Court concluded that it is not always possible to exclude the application of the reformatio in peius principle to administrative proceedings, but it is necessary to take into account the circumstances of each case. Accordingly, it is necessary to take into account not only the rights of the accused company, but also the public interest. Cartel agreements are meant to benefit its members only. At the same time, they harm consumers and competition.

The applicant subsequently submitted a complaint to the Constitutional Court of the Slovak Republic. In the complaint, the applicant argued, inter alia,

21 As specified in the judgement of the ECHR of 23 November 1976 in case of Engel and others $v$. Netherlands (application no 5100/71; 5101/71; 5102/71; 5354/72; 5370/72): the nature of the offence and the degree of stigma attached to it, the severity of the possible penalty, and the classification of the offence under domestic law

22 See e.g. the Judgement of the ECHR of 23 November 2006 in case of Jussila v. Finland.

23 Judgement of the Court of the First Instance in Joined Cases T-101/05 and T-111/05 $B A S F A G, U C B S A$, ECLI:EU:T:2007:380. 
that the AMO in the $2^{\text {nd }}$ instance proceedings imposed its financial penalty in an erroneous manner in that it increased the fine imposed in the $1^{\text {st }}$ instance decision. According to the applicant, the AMO breached that company's right to a fair trial.

The Constitutional Court reviewed the decision of the Supreme Court and came to the conclusion that no breach of the rights of SIEMENS AG had taken place ${ }^{24}$.

The Constitutional Court analyzed the application of criminal proceedings to competition proceedings in greater detail. According to the Court, in such cases it is necessary to search for the intersection between criminal and administrative law. The relation between criminal and administrative law is twofold.

First, a type of administrative proceedings exists which may be seen as a continuation of criminal proceedings. These types of proceedings are of a quasi-criminal nature and are so close to criminal proceedings that procedural rights immanent to criminal proceedings apply naturally to such administrative proceedings also. This group includes, for example, proceedings on minor offences of natural persons ${ }^{25}$.

When it comes to the second type of administrative proceedings, it is necessary to search for those procedural rights immanent to criminal proceedings, which should be applied therein.

However, there is no reason to interpret the legal order so as to see all sanctions imposed in administrative proceedings as being criminal in nature.

The Constitutional Court stated that the mere fact that the law allows for the imposition of a fine, which could amount to millions of EUR, could not automatically mean that the fine is not proportionate, since high fines are natural to competition law. Moreover, fines are usually imposed on undertakings of significant economic strength and importance.

The Constitutional Court referred to the Engel Criteria. According to the second Engel Criterion, it is important to distinguish between the preventiverepressive and the reparative purpose of the fine.

The Constitutional Court stated that in cartel cases, the function of the fine lies in the 'reparation of the effects of the infringement'. Therefore, fines do not fulfill a primarily preventive or repressive function. As a result, the fine imposed by the AMO was not of a quasi-criminal nature.

The Constitutional Court further stressed the distinctions between criminal and administrative proceedings. The purpose of the application of the reformatio in peius principle is to establish a balance between the infringement

24 Decision of the Constitutional Court of 13 January 2016, I. US 505/2015-55/.

25 See e.g. judgement of the ECtHR of 2 September 1998 in case of Lauko v. Slovakia $(4 / 1998 / 907 / 1119)$. 
and the sanction imposed for that infringement. Establishing such balance is more complex in criminal proceedings. While an appeal brought by the state attorney may lead to stricter sanctions in criminal proceedings, this is not possible in administrative proceedings. In the latter, there is no adverse party (similar to the state attorney) that would protect the public interest. An interpretation whereby reformatio in peius in an appeal procedure is not allowed would thus be in conflict with the purpose of the appeal procedure in administrative proceedings.

\section{Conclusions}

As seen from the above, the GIS cartel generated several interesting issues.

When it comes to the parental liability concept, Slovak courts did not clearly state to what an extent it is applicable to Slovak competition law proceedings. Neither did they further examine the conditions of its application in the national legal order. This question remains therefore, for the most part, unresolved.

The conclusions reached by the domestic judiciary with respect to the parallel competences of the European Commission and NCAs were limited to one particular situation only - infringements that took place before and after the accession of a Member State to the European Union. However, other questions remain unanswered in relation to 'possible' conflicts between the competences of the Commission and NCAs according to Regulation 1/2003.

On the other hand, the conclusions of the Slovak Constitutional Court as regards the reformatio in peius principle are appreciable, since it expressed its position more clearly towards the application of criminal law principles to competition law proceedings. These conclusions should be welcomed since the nature of competition proceedings does not allow for the application of all criminal law principles to these types of proceedings.

\section{References}

Ivor, J. et al. (2010). Criminal Procedural Law. Second Edition. Bratislava: Iura Edition. Sramelova, S. and Blazo, O. (2015). The First Bid Rigging Case in Slovakia After Years of Judicial Disputes, YARS, 8 (11), 249-260, http://dx.doi.org/10.2139/ssrn.2741673. 